Naples ; Dr. K. Schofield, reader in organic chemistry, University of Exeter, for a study of the techniques of nucleic acid chemistry ; Prof. F. C. Thompson, professor of metallurgy, University of Manchester, for a metallurgical investigation of the techniques of production of ancient coins; and M. J. Webb, lecturer in geography, University of Oxford, for a study of weather and rainfall in India. Further information about the awards can be obtained from the Secretary, Leverhulme Research Awards, St. Bridget's House, Bridewell Place, London, E.C.4.

\section{Portsmouth College of Technology: Golden Jubilee Research Fund}

THE City of Portsmouth College of Technology, which was accorded regional college status by the Ministry of Education last year, has almost doubled in size in the past five years, now having more than seven thousand students, of whom more than nine hundred are full-time and sandwich course students and some are research workers. It serves, through its advanced courses in science and technology, the whole of the Southern Region consisting of the counties of Hampshire, the Isle of Wight, Dorset, West Sussex, Wiltshire, Berkshire and Oxfordshire. Portsmouth Education Authority has given generous support in helping to solve problems arising from these developments, but even so, considerable strain has recently been imposed on College finances, especially in the field of research. The College this year celebrates its golden jubilee with an open day, to be held on May 30, and in this connexion is putting forward an appeal for subscriptions towards a research fund. The College believes that if it is adequately to perform its function of educating and training the scientists and technologists of the future, there is an ever-increasing need for close association between industry and the eollege, particularly in research and consultative work. The existing association, already strengthened through the formation of advisory committees, would, it is felt, be further reinforced by the establishment of a research fund in this way. Contributions to the fund and any requests for further information should be addressed to the Registrar, City of Portsmouth College of Technology.

\section{Scientific Literature concerning Fire}

THE Department of Scientific and Industrial Research and Fire Offices' Committee Joint Fire Research Organization issue a comprehensive bibliography of references to scientific literature on fire. Part 8 (References to Scientific Literature on Fire, Part 8, 1954. By Miss E. M. Shakeshaft and Mrs. B. F. W. Rogowski. Pp. 126. (Library Bibliography No. 5/Part 8. Boreham Wood, Herts : Fire Research Station, 1958) contains 1,242 entries arranged under seven heads : occurrence of fire; fire hazards; initiation and development of combustion; fire precautions ; fire-resistance ; fire-fighting ; and general. There are also an author index and an alphabetical subject index.

\section{Arid Zone Research}

THe Unesco publication "Climatology-Roviews of Research", No. 10 in the series "Arid Zone Research" (Pp. 190. Paris : Unesco ; London : H.M. Stationery Office, 1958. 5 dollars) presents valuable reviews of present knowledge of a number of climatological and bioclimatological subjects, commissioned for the symposium on arid zone climatology held at Canberra in 1956. The reviews deal with evaporation and the water balance; climatic factors in animal ecology; radiation and thermal balance; climates and vegeta. tion; effects of climate on man and animals and their modification by clothing and shelter; modification of microclimates by vegetation, shelter belts, alteration of radiating surface, irrigation, etc.; chemical climate and saline soils in the arid zonemainly a reviow of the distribution of chlorides and sulphur; climatological observational requirements in arid zones. They are all very thorough and valuable reviews with large bibliographies, but more account should have been taken of the extensive work in these subjects carried out in recent years in the U.S.S.R. Only one of the reviews-on modifica. tion of microclimates-refers to Soviet work and then only briefly and almost entirely from abstracts published by the American Meteorological Society.

\section{Use of Fluorescent Lighting for Experiments on Photoperiodism}

Fluorescent lamps are frequently used as the source of illumination in the investigation of photoperiodic effects in plants and animals. Since such responses are often elicited by extremely low intensities of illumination, great care is taken to ensure that experimental chambers are completely lightproof. Drs. J. W. L. Beament and A. D. Lees (Agricultural Research Council Unit of Insect Physiology, Department of Zoology, Cambridge) write : "During routine examination of a cabinet equipped with five 40-watt 'daylight' fluorescent tubes, controlled through a conventional single-pole time-switch, a flickering white light was observed in each tube with the dark-adapted eye, even though the clock mains switch was 'off'. It was found that the time-switch was operating in the neutral side of the mains supply, and that the trouble was completely eliminated by switching in the live side. The ability of a fluorescent tube to show a gas-discharge glow when merely capacitatively coupled to an a.c. mains supply, although well known to electrical engineers and others, is certainly not sufficiently familiar to biological workers, and may possibly interfere with some types of experiment".

\section{Colloquium Ampère, 1957}

A REPORT of the proceedings of the Sixth Colloquium Ampère, which was held at St. Malo during April 24-26, 1957, sppeared in Nature (179, 1343; 1957). The texts of the seventy-three contributions presented have since been published in the special number of Vol. 10 of the Archives des Sciences. Twelve different nationalities are represented, and more than a hundred research workers took part in the meeting. The subjects discussed included dielectrics; rotatory polarization; paramagnetic, nuclear magnetic and quadripolar resonence; the ammonia maser and the Overhauser effect. All the articles are very brief, and the absence of general survey talks such as have been given at previous colloquia is to be regretted.

\section{British Agricultural History Society : Officers}

AT the annual general meeting of the British Agricultural History Society, held at the Yorkshire (West Riding) Institute of Agriculture at Askham Bryan on April 11, the following officers were reelected for the year 1958-59 : President, Sir James Scott Watson; Treasurer, Prof. E. Thomas (Reading); 